\title{
Degradation of Anthocyanin Content in Sour Cherry Juice During Heat Treatment
}

\author{
Lilla Szalóki-Dorkó ${ }^{1}$, György Végvári²*, Márta Ladányii, Gitta Ficzek ${ }^{4}$ and \\ Mónika Stéger-Máté \\ ${ }^{1}$ Department of Food Preservation, Faculty of Food Science, Corvinus University of Budapest, \\ Villányi út 29-43, HU-1118 Budapest, Hungary \\ ${ }^{2}$ Department of Soil Science and Water Management, Faculty of Horticultural Science \\ Corvinus University of Budapest, Villányi út 29-43, HU-1118 Budapest, Hungary \\ ${ }^{3}$ Department of Biometrics and Agrarinformatics, Faculty of Horticultural Science, \\ Corvinus University of Budapest, Villányi út 29-43, HU-1118 Budapest, Hungary \\ ${ }^{4}$ Department of Fruit Science, Faculty of Horticultural Science, Corvinus University \\ Corvinus University of Budapest, Villányi út 29-43, HU-1118 Budapest, Hungary \\ Received: October 6, 2014 \\ Accepted: April 20, 2015
}

\begin{abstract}
Summary
Sour cherry juices made from two sour cherry cultivars (Érdi bőtermő and Kántorjánosi 3) were investigated to determine their total anthocyanin content and half-life of anthocyanins during heat treatment at different temperatures $\left(70,80\right.$ and $\left.90{ }^{\circ} \mathrm{C}\right)$ for $4 \mathrm{~h}$. Before the heat treatment, Érdi bőtermő juice had higher anthocyanin concentration $(812 \mathrm{mg} / \mathrm{L})$ than Kántorjánosi 3 juice $(513 \mathrm{mg} / \mathrm{L})$. The greatest heat sensitivity of anthocyanins was measured at $90{ }^{\circ} \mathrm{C}$, while the treatments at 80 and $70{ }^{\circ} \mathrm{C}$ caused lower thermal degradation. The loss of anthocyanins in Érdi bőtermő juice after treatment was 38, 29 and $18 \%$, respectively, while in Kántorjánosi 3 juice losses of 46, 29 and $19 \%$ were observed, respectively. At $90^{\circ} \mathrm{C}$ sour cherry Érdi bőtermő juice had higher half-life $\left(t_{1 / 2}\right)$ of anthocyanins, while the Kántorjánosi 3 juice had higher $t_{1 / 2}$ values at $70{ }^{\circ} \mathrm{C}$. Cyanidin-3-glucosyl-rutinoside was present in higher concentrations in both cultivars (Érdi bőtermő: 348 and Kántorjánosi 3: $200 \mathrm{mg} / \mathrm{L}$ ) than cyanidin-3-rutinoside (177 and $121 \mathrm{mg} / \mathrm{L}$ ) before treatment. However, during the experiment, cyanidin-3-rutinoside was proved to be more resistant to heat. Comparing the two varieties, both investigated pigment compounds were more stable in Kántorjánosi 3 than in Érdi bőtermő. Degradation rate of anthocyanins was cultivar-dependent characteristic, which should be taken into account in the food production.
\end{abstract}

Key words: Prunus cerasus, half-life of anthocyanins, heat degradation, colour changes, HPLC, juice

\section{Introduction}

Nowadays, healthy diet is becoming more and more important with key elements like fruits and vegetables. These have a high content of biologically active compounds that contribute to good health and prevention of several diseases. Sour cherry (Prunus cerasus L.) is the second most important fruit in Hungary (after apple) with the yield of 53 thousand tonnes per year (1). In the fruit industry, sour cherry is processed to puree, concentrate, juice and canned fruit. Purees are used in the bakery, confectionary or dairy industry, while juices and concentrates 
serve as the base of fruit nectars and fruit beverages. Concentrates are highly esteemed by the industry due to their intensive taste and colour (2).

The total anthocyanin content of some European sour cherry cultivars ranges from 569 to $858 \mathrm{mg} / \mathrm{L}$, and anthocyanins mostly (approx. $80 \%$ ) consist of cyanidin compounds $(2,3)$. In sour cherry fruit the main anthocyanin component is cyanidin-3-glucosyl-rutinoside, which gives $60-70 \%$ of total anthocyanin content, while the second major pigment is cyanidin-3-rutinoside at 25-33\% $(4,5)$. The following components have been found in sour cherry as well: cyanidin-3-sophoroside, cyanidin-3-glucoside $(4,6)$, peonidin-3-glucoside (7) and peonidin-3-rutinoside (8).

However, the anthocyanin concentration in sour cherry products greatly differs depending on the method of processing. Thermal processing includes a heat treatment with maximum temperatures from 50 to $150{ }^{\circ} \mathrm{C}$, depending on the $\mathrm{pH}$ of the product and the desired shelf life (9).

Anthocyanin pigments rapidly degrade during thermal processing because they are heat sensitive $(10,11)$, which can have a dramatic impact on colour quality and may also affect nutritional properties (9). Knowledge of anthocyanin degradation kinetics, including reaction order, rate constant $(k)$ and half-life $\left(t_{1 / 2}\right)$ is very important to predict food quality loss during thermal processing. Therefore, kinetic studies are much needed in order to minimize the undesired degradation, and to optimize the quality of specific foods $(9,12)$. Under isothermal conditions, degradation of sour cherry anthocyanins in both juice and concentrates is characterized by first order kinetics (13)

There are several studies dealing with the effect of heat treatment on pigment concentration in fruits. Elderberry anthocyanins showed very high sensitivity to thermal treatment. After $3 \mathrm{~h}$ of heating at $95{ }^{\circ} \mathrm{C}$, only $50 \%$ of elderberry pigments remained (14). Carrying out thermal treatment at high temperature $\left(95{ }^{\circ} \mathrm{C}\right)$ in combination with pasteurisation during the production of blueberry purees resulted in $43 \%$ loss of total monomeric anthocyanins, compared to original levels found in fresh fruit (15). Other authors demonstrated that cyanidin-3-glucoside and pelargonidin-3-glucoside in blackberry and strawberry purees were significantly affected by thermal treatment at $70{ }^{\circ} \mathrm{C}$ for $2 \mathrm{~min}$ (16). In contrast, Rhim (17) and Kirca et al. (18) reported that anthocyanins from black carrots were reasonably stable during heating at 70, 80 and $90{ }^{\circ} \mathrm{C}$. Based on these studies, the degree of thermal degradation of anthocyanins depends on several conditions such as magnitude and duration of heating, and characteristics of anthocyanins and raw materials.

In this study, changes of total anthocyanin content and two major anthocyanins, cyanidin-3-glucosyl-rutinoside and cyanidin-3-rutinoside are studied in two cherry juices during heat treatment at different temperatures and periods. Further aim is to determine the kinetic parameters of anthocyanin degradation in sour cherry juices in order to help to improve the predictions of quality loss.

\section{Materials and Methods}

\section{Plant material}

Érdi bőtermő and Kántorjánosi 3 (two Hungarian sour cherry cultivars) were investigated. The fruit samples were collected from the experimental field of the Research Institute for Fruit Growing and Ornamentals in Érd-Elvira major in Érd, Hungary. The fruits were picked at their optimum maturity stage in June 2011.

\section{Chemicals and reagents}

The HPLC grade solvents acetonitrile (ACN) and methanol $(\mathrm{MeOH})$ and glacial acetic acid were purchased from Sigma-Aldrich Chemical Co. (St. Louis, MO, USA), and the analytical standards of cyanidin-3-glucosyl-rutinoside (Cy-3-GR) and cyanidin-3-rutinoside (Cy-3-R) from Polyphenols Laboratories AS (Sandness, Norway). Ethanol and hydrochloric acid were obtained from Reanal (Budapest, Hungary). Fructozym P enzyme, Klar-Sol Super and ErbiGel were purchased from Kerttrade Kft. (Dunavarsány, Hungary).

\section{Juice preparation}

Sour cherry juices from Érdi bőtermő and Kántorjánosi 3 cultivars were prepared according to industrial protocols under laboratory conditions. Sour cherries were heated to $80-85^{\circ} \mathrm{C}$ in order to inactivate enzymes and to make the juice extraction easier. Then the heated samples were cooled to $40-45{ }^{\circ} \mathrm{C}$ and Fructozym $\mathrm{P}$ enzyme was added $(0.1 \mathrm{~mL} / \mathrm{kg}$, treatment time: $60 \mathrm{~min})$. The enzymatic treatment was followed by pressing of the fruits, and Fructozym $\mathrm{P}$ was added to the pressed juice again (0.05 $\mathrm{mL} / \mathrm{L}$, treatment time: $20-25 \mathrm{~min})$. After that, pectin test was performed by adding ethanol to sour cherry juice at a ratio of 2:3. The desired clear solution (negative result) indicated that pectin molecules were broken down during enzymatic treatment. Silica $0.5 \mathrm{~mL} / \mathrm{L}$ (Klar-Sol Super) and gelatin $0.1 \mathrm{~g} / \mathrm{L}$ (ErbiGel) were added to the pressed juice and left to stand for approx. $30 \mathrm{~min}$. The clear upper layer was then filtered under vacuum (10 mbar) through diatomaceous earth.

\section{Heat treatment}

Glass tubes were filled with clarified and filtered juices made from two sour cherry cultivars and these tubes were immersed in a water bath and heated to 70, 80 and $90{ }^{\circ} \mathrm{C}$. The sampling was made $30,60,90,120,180$ and 240 min later. After sampling, tubes were immediately cooled in ice water to stop further thermal degradation. Finally, the samples were tested with various methods to determine the effect of heat treatment on anthocyanins and on colour stability of sour cherries. The measurements were done in triplicate in each case.

\section{Total anthocyanin content and browning ratio}

Total anthocyanin content and browning ratio were determined according to the method of Füleki and Francis (19). Hydrochloric acid and ethanol were used for anthocyanin extraction. Absorbance was measured at 530 nm with U-2900A spectrophotometer (Hitachi High-Tech, 
Tokyo, Japan). The total anthocyanin content was expressed in $\mathrm{mg}$ of cyanidin-3-glucoside (Cy-3-G) equivalents per L of sour cherry juice. Total anthocyanin content (in $\mathrm{mg} / \mathrm{L}$ ) was calculated as follows:

$$
\gamma(\text { anthocyanin })=A_{\max } \cdot 15 \cdot \text { dilution }
$$

The browning can be used as a quality indicator of the samples, and it was determined based on the absorbances at minimum $(410 \mathrm{~nm})$ and maximum $(530 \mathrm{~nm})$ wavelengths (19), using the following equation:

$$
\text { Browning }=A_{\min } / A_{\max }
$$

\section{HPLC analysis of two major anthocyanins}

The standards $(0.5 \mathrm{mg} / \mathrm{mL})$ were dissolved in methanol containing $0.1 \%$ (by volume) hydrochloric acid and $50 \times$ dilution was adopted as the working standard for HPLC. The Waters high-performance liquid chromatograph (Waters Co., Milford, MA, USA) was equipped with a dual absorbance detector (2487 Dual $\lambda$ ), a binary HPLC pump (1525), an in-line degasser, a column thermostat (set at $40{ }^{\circ} \mathrm{C}$ ) and an autosampler (717 plus), and was controlled using Empower ${ }^{\mathrm{TM}}$ v. 2 software (Waters Co.). A Kinetex 2.6u C18 100A $150 \mathrm{~mm} \times 4.6 \mathrm{~mm}$ column (Phenomenex Torrance, CA, USA) was installed, and the mobile phase was $2.5 \%$ glacial acetic acid containing water, $\mathrm{MeOH}$ and ACN (35:5:10). The isocratic flow rate was set to $1 \mathrm{~mL} / \mathrm{min}$, the running time was $15 \mathrm{~min}$, while pressure in the column was $(372 \pm 1)$ bar. Each injected volume was $20 \mu \mathrm{L}$. The samples were analyzed at $520 \mathrm{~nm}$. Before injections, all samples were filtered through $0.45-\mu \mathrm{m}$ Millex-HV PVDF syringe-driven filter unit (Millipore Co., Billerica, MA, USA). All measurements were carried out in triplicates.

\section{Calculation of half-life of anthocyanins}

With some exceptions $(20,21)$, first-order kinetics $(13,22-24)$ has been found suitable for determination of anthocyanin decomposition under both aerobic and anaerobic conditions. The first-order reaction rate constant $(k)$ and half-life $\left(t_{1 / 2}\right)$, i.e. the time needed for $50 \%$ of anthocyanins to degrade, were calculated with the following equations (25):

$$
\begin{aligned}
& \ln \left(\gamma_{\mathrm{t}} / \gamma_{0}\right)=-k \cdot t \\
& t_{1 / 2}=-\ln 0.5 / k
\end{aligned}
$$

where $\gamma_{0}$ is the initial anthocyanin concentration and $\gamma_{\mathrm{t}}$ is the anthocyanin concentration after time $t(\mathrm{~min})$ of heating at a given temperature (depending on the given experiment).

\section{Statistical analysis}

Statistical analysis was carried out using SPSS v. 20 software (IBM Corp., Armonk, NY, USA). A two-factor (treatment temperature and cultivar) ANOVA was done to determine their effect on total anthocyanin content and browning. In order to normalize the data of total anthocyanin content, logarithmic transformation was executed. Since the assumption of sphericity was violated both for total anthocyanin $(\varepsilon=0.61)$ and browning $(\varepsilon=0.66)$, we applied the Greenhouse-Geisser's correction to test the within-subject effects. We also considered that the effect of size measure (denoted by partial $\eta^{2}$ ) is the variance explained by a given independent factor of the variance remaining after excluding the variance explained by other independent factors as well as the observed power of the test. Normality of residuals was proved using the ShapiroWilk's test $(p>0.05)$. Homogeneity of variances was tested by Levene's test $(p>0.05)$ and, depending on the significance level, it was followed by Tukey's or Games-Howell's post hoc test for the treatment temperature. Pairwise comparisons of the total anthocyanins and browning results measured after different time intervals were made by Bonferroni's test.

\section{Results and Discussion}

\section{Changes in total anthocyanin content during heat treatment}

Total anthocyanin content of Érdi bőtermő and Kántorjánosi 3 juices was 811 and $513 \mathrm{mg} / \mathrm{L}$, respectively (Table 1). In other studies where the pigment concentration of sour cherry juice was similarly investigated, the monomeric anthocyanin content of juice was measured within the range of $350-633 \mathrm{mg} / \mathrm{L}(4,5)$.

Table 1 shows that the treatment at $90{ }^{\circ} \mathrm{C}$ had the greatest impact on the anthocyanin content of Érdi bőtermő juices, where pigment concentration decreased from 812 to $501 \mathrm{mg} / \mathrm{L}$ (38 \%). Degradation was lower at 80 ${ }^{\circ} \mathrm{C}$, and the treatment for $4 \mathrm{~h}$ at this temperature resulted in $29 \%$ loss of total anthocyanin content (573 mg/L) compared to the original levels found in fresh juice.

In the treatment at $70{ }^{\circ} \mathrm{C}$, the degree of anthocyanin degradation was $18 \%$, resulting in $667 \mathrm{mg} / \mathrm{L}$ of anthocyanins. This shows that sour cherry pigments were the least susceptible to degradation at the lowest treatment temperature. The greatest reduction was observed after 120 min of heating which is, therefore, considered to be a critical point of heat treatment. Pigment concentration decreased more than $10 \%$ at all treatment temperatures in samples of Érdi bőtermő.

The average total anthocyanin content in Kántorjánosi 3 juices was $513 \mathrm{mg} / \mathrm{L}$ before the treatments (Table 1), which is $37 \%$ less than the initial value in Érdi bötermő juices. Degradation rates in Érdi bőtermő juice at different temperatures were similar to those in Kántorjánosi 3 juice. The total pigment concentration decreased from 513 to $278 \mathrm{mg} / \mathrm{L}\left(46 \%\right.$ loss) at $90{ }^{\circ} \mathrm{C}$. In a similar study, lower degradation rates of sour cherry anthocyanins were observed at 80 and $70{ }^{\circ} \mathrm{C}$, and pigment concentration decreased by 29 and $19 \%$ after 240 min of heat treatment. Similar degradation rates were observed in blackberry and black carrot anthocyanins at 70 and $80^{\circ} \mathrm{C}(24,25)$.

In our study, both between-subject effects (treatment temperature and cultivar) as well as the elapsed time (i.e. within-subject effect) had significant impact on the results $\left(\mathrm{F}_{\text {temperature }}(2 ; 12)=131.65\right.$ with $\mathrm{p}<0.001 ; \mathrm{F}_{\text {cultivar }}(1 ; 12)=2611.87$ with $\mathrm{p}<0.001$ and $\mathrm{F}_{\text {time }}(3.68 ; 44.17)=109.68$ with $\mathrm{p}<0.001$, respectively) of total anthocyanins. Partial $\eta^{2}$ value was higher than 0.90, while the statistical power of the test 
Table 1. Total anthocyanin content in sour cherry juices during heat treatment

\begin{tabular}{|c|c|c|c|c|c|c|}
\hline \multirow{4}{*}{$t / \mathrm{min}$} & \multicolumn{6}{|c|}{$\gamma($ total anthocyanins $) /($ mg of Cy-3-G per L) } \\
\hline & \multicolumn{3}{|c|}{ Érdi bőtermő } & \multicolumn{3}{|c|}{ Kántorjánosi 3} \\
\hline & \multicolumn{6}{|c|}{ Temperature $/{ }^{\circ} \mathrm{C}$} \\
\hline & 90 & 80 & 70 & 90 & 80 & 70 \\
\hline 0 & $(812 \pm 21)^{\mathrm{Ab}}$ & $(812 \pm 21)^{\mathrm{Ab}}$ & $(812 \pm 21)^{\mathrm{Ab}}$ & $(513 \pm 27)^{\mathrm{Ab}}$ & $(513 \pm 27)^{\mathrm{Ab}}$ & $(513 \pm 27)^{\mathrm{Ab}}$ \\
\hline 30 & $(714 \pm 21)^{\mathrm{Ab}}$ & $(763 \pm 15)^{\text {Aab }}$ & $(749 \pm 67)^{\mathrm{Aab}}$ & $(465 \pm 32)^{\mathrm{Aab}}$ & $(504 \pm 31)^{\mathrm{Aa}}$ & $(489 \pm 4)^{\mathrm{Aa}}$ \\
\hline 60 & $(671 \pm 17)^{\mathrm{Ab}}$ & $(710 \pm 10)^{\mathrm{Ab}}$ & $(740 \pm 61)^{\mathrm{Ab}}$ & $(404 \pm 27)^{\mathrm{Aab}}$ & $(425 \pm 32)^{\mathrm{ABa}}$ & $(480 \pm 1)^{\mathrm{Ba}}$ \\
\hline 90 & $(617 \pm 27)^{\mathrm{Aab}}$ & $(696 \pm 3)^{\mathrm{Bb}}$ & $(729 \pm 13)^{\mathrm{Bb}}$ & $(379 \pm 3)^{\mathrm{Ab}}$ & $(428 \pm 4)^{\mathrm{Ba}}$ & $(480 \pm 15)^{\mathrm{Ca}}$ \\
\hline 120 & $(604 \pm 74)^{\mathrm{ABab}}$ & $(676 \pm 7)^{\mathrm{Aab}}$ & $(720 \pm 11)^{\mathrm{Bab}}$ & $(360 \pm 21)^{\mathrm{Aab}}$ & $(406 \pm 18)^{\mathrm{Ba}}$ & $(481 \pm 8)^{\mathrm{Ca}}$ \\
\hline 180 & $(529 \pm 27)^{\mathrm{Aab}}$ & $(585 \pm 11)^{\mathrm{Ba}}$ & $(651 \pm 13)^{\mathrm{Ca}}$ & $(312 \pm 23)^{\mathrm{Aab}}$ & $(398 \pm 8)^{\mathrm{Ba}}$ & $(451 \pm 20)^{\mathrm{Ba}}$ \\
\hline 240 & $(501 \pm 9)^{\mathrm{Aa}}$ & $(573 \pm 55)^{\mathrm{ABab}}$ & $(667 \pm 22)^{\mathrm{Bab}}$ & $(278 \pm 7)^{\mathrm{Aa}}$ & $(365 \pm 6)^{\mathrm{Ba}}$ & $(416 \pm 50)^{\mathrm{ABa}}$ \\
\hline
\end{tabular}

The values are expressed as mean \pm standard deviation (S.D.), based on $N=3$ replicates. $C y-3-G=$ cyanidin-3-glucoside. Different upper case letters indicate significant differences among treatments at different temperatures during the same time of treatment (read from left to right), whereas different lower case letters indicate significant differences among different treatment times at a given temperature (read from up downwards)

was higher than 0.99 in each case. Interaction between temperature and the elapsed time or cultivar was significant $\left(\mathrm{F}_{\text {temperaturextime }}(7.36 ; 44.17)=9.17\right.$ with $\mathrm{p}<0.001$ and $\eta^{2}=0.6$, $\mathrm{F}_{\text {temperaturexcultivar }}(2 ; 12)=5.99$ with $\mathrm{p}<0.05$ and $\eta^{2}=0.5$, statistical power is higher than 0.75 in both cases), however, it was insignificant between elapsed time and cultivar $\left(\mathrm{F}_{\text {timexcultivar }}\right.$ $(3.68 ; 44.17)=1.49$ with $p=0.22)$ and for three-level type interaction $\left(\mathrm{F}_{\text {timextemperaturexcultivar }}(7.36 ; 44.17=1.02\right.$ with $\mathrm{p}=0.43)$.

\section{Concentration of two major anthocyanins in sour cherry during heat treatment}

High-performance liquid chromatography analysis of sour cherry juices revealed the presence of two major anthocyanin peaks, i.e. Cy-3-GR and Cy-3-R with retention times at 4.22 and $4.86 \mathrm{~min}$, respectively (Fig. 1). Other anthocyanins were present in a lower amount. The results demonstrate that Cy-3-GR is the major anthocyanin in both sour cherry cultivars, which is in accordance with the data of other authors $(2,26,27)$. Before the heat treatment, the concentrations of Cy-3-GR and Cy-3-R in Érdi bőtermő juice were 348 and $177 \mathrm{mg} / \mathrm{L}$, while in Kántorjánosi 3 juice they were 200 and $121 \mathrm{mg} / \mathrm{L}$, respectively. These values represent 43 and $22 \%$ of total anthocyanins in Érdi bőtermő juice, and 39 and 24 \% in Kántorjánosi 3 juice. Therefore, these two identified anthocyanin compo-

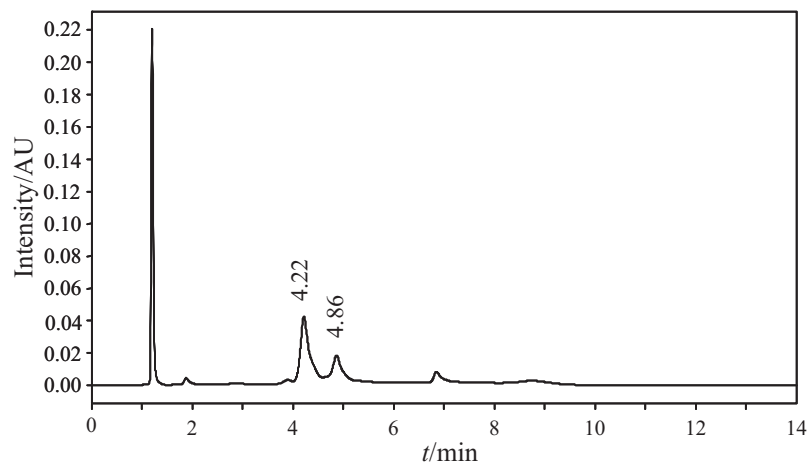

Fig. 1. Typical HPLC chromatogram of sour cherry juices measured at $A=520 \mathrm{~nm}$ nents represented more than $60 \%$ of total pigment concentration in both sour cherry juices. Jakobek et al. (28) detected Cy-3-GR and Cy-3-R in sour cherry juice as well; in much lower concentrations of 183 and $93 \mathrm{mg} / \mathrm{L}$, respectively.

According to our data the heat treatment caused significant reduction in the quantity of the two major anthocyanin components, as expected. The content of Cy-3-GR in Érdi bőtermő juice (Fig. 2) was reduced to $124 \mathrm{mg} / \mathrm{L}$ at $90{ }^{\circ} \mathrm{C}$. Lower degradation was observed at 80 and $70{ }^{\circ} \mathrm{C}$, which means that the concentration of this major pigment decreased to 198 and $263 \mathrm{mg} / \mathrm{L}$, respectively, after $240 \mathrm{~min}$ of heating. Concentration of $\mathrm{Cy}-3-\mathrm{R}$ was reduced to 58.4 $\mathrm{mg} / \mathrm{L}$ at the highest treatment temperature, while 94.4 and $131 \mathrm{mg} / \mathrm{L}$, respectively, were detected at 80 and $70{ }^{\circ} \mathrm{C}$.

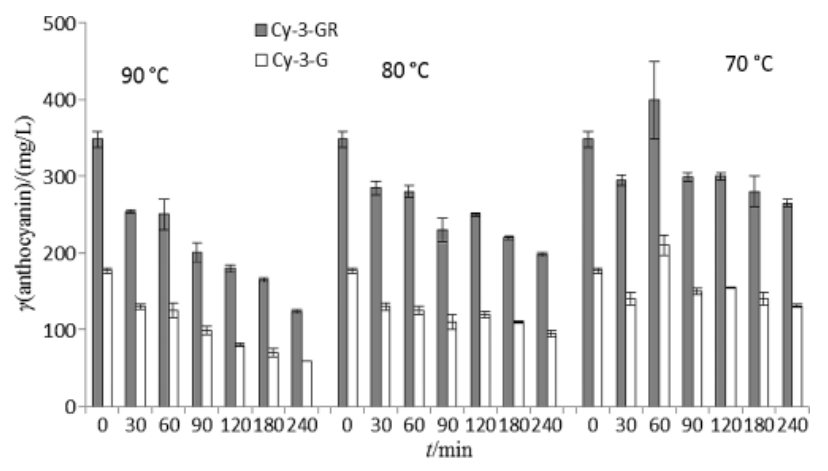

Fig. 2. Concentration of cyanidin-3-glucosyl-rutinoside (Cy-3$-\mathrm{GR})$ and cyanidin-3-rutinoside $(\mathrm{Cy}-3-\mathrm{R})$ in Érdi bőtermő juice during heat treatment

Similar trend of decrease was observed in Kántorjánosi 3 juice. The loss of Cy-3-GR was $68 \%$; its value decreased from 200 to $64.0 \mathrm{mg} / \mathrm{L}$ at $90{ }^{\circ} \mathrm{C}$, to $116 \mathrm{mg} / \mathrm{L}$ at 80 ${ }^{\circ} \mathrm{C}$, while $140 \mathrm{mg} / \mathrm{L}$ were measured at the lowest temperature after $240 \mathrm{~min}$ (Fig. 3). Cy-3-R was also sensitive to heat treatment, as $74 \%$ lower value $(31.4 \mathrm{mg} / \mathrm{L})$ was measured after the heating treatment at $90{ }^{\circ} \mathrm{C}$, while the degradation at 80 and $70{ }^{\circ} \mathrm{C}$ was lower, and 67.8 and 85.6 $\mathrm{mg} / \mathrm{L}$, respectively, of Cy-3-R remained. 


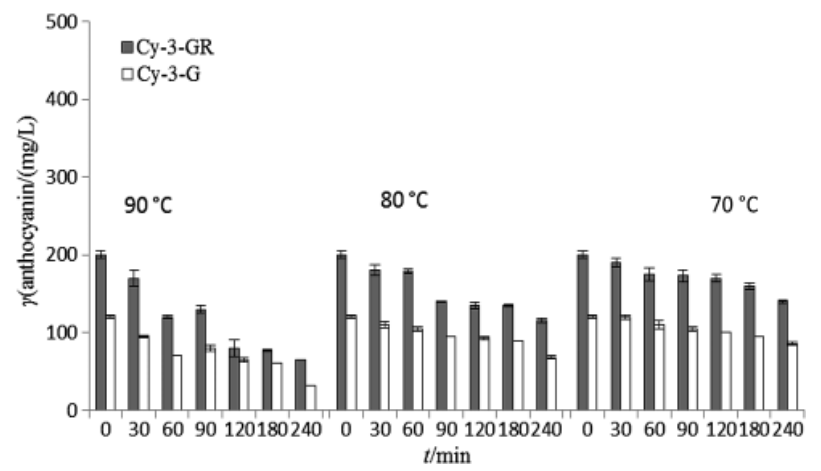

Fig. 3. Concentration of cyanidin-3-glucosyl-rutinoside (Cy-3-GR) and cyanidin-3-rutinoside (Cy-3-R) in Kántorjánosi 3 juice during heat treatment

Comparing the two investigated sour cherry juices, the two major anthocyanin components were more stable in Kántorjánosi 3 juice although its total anthocyanin concentration was lower than in Erdi bőtermő juice. Cy-3-R is more resistant to the heat treatment than Cy-3-GR, which was also reported by Verbyest et al. (22) in raspberries. The amount of Cy-3-GR is almost twice higher than of Cy-3-R in both of the two sour cherry cultivars throughout the whole experiment.

\section{Stability of anthocyanins during heat treatment}

As expected, the degradation of anthocyanins depended on temperature, being greater at higher temperatures (Table 2). This trend was similar to the results of other investigations of different sources of anthocyanins such as black carrot (25) and blood orange (29). Comparing the two sour cherry cultivars, Érdi bőtermő juices had higher $t_{1 / 2}$ values than Kántorjánosi 3 juices at $90{ }^{\circ} \mathrm{C}$ in most cases, which means that anthocyanins from Érdi bőtermő juice were more sensitive to the treatment at the highest temperature. However, total pigment content in Kántorjánosi 3 decreased faster at $70{ }^{\circ} \mathrm{C}$ than in Érdi bőtermő juices (Table 2). Based on the kinetic results, it can be concluded that heat stability of anthocyanins in sour cherry juices depended on the cultivar. Sour cherry anthocyanins were less susceptible to higher tempera- tures than blackberry anthocyanins. The different susceptibilities of fruit juice anthocyanins to heat might be due to their different anthocyanidin composition (30).

\section{Browning of sour cherry juices}

Table 3 shows different degrees of browning of the juices of two sour cherry cultivars after $240 \mathrm{~min}$ of heating, except for the Érdi bőtermő juice treated at $70{ }^{\circ} \mathrm{C}$,

Table 2. Kinetic parameters for the degradation of monomer anthocyanins in sour cherry juices

\begin{tabular}{|c|c|c|c|c|}
\hline \multirow{2}{*}{$t / \mathrm{min}$} & \multicolumn{2}{|c|}{ Érdi bőtermő } & \multicolumn{2}{|c|}{ Kántorjánosi 3} \\
\hline & $-k \cdot 10^{-3} / \mathrm{min}^{-1}$ & $t_{1 / 2} / \mathrm{h}$ & $-k \cdot 10^{-3} / \mathrm{min}^{-1}$ & $t_{1 / 2} / \mathrm{h}$ \\
\hline & \multicolumn{4}{|c|}{ at $90^{\circ} \mathrm{C}$} \\
\hline 30 & 4.3 & 2.7 & 3.3 & 3.5 \\
\hline 60 & 3.2 & 3.6 & 3.9 & 2.9 \\
\hline 90 & 3.0 & 3.8 & 3.4 & 3.4 \\
\hline 120 & 2.5 & 4.7 & 2.9 & 3.9 \\
\hline 180 & 2.4 & 4.9 & 2.8 & 4.2 \\
\hline \multirow[t]{2}{*}{240} & 2.0 & 5.7 & 2.5 & 4.5 \\
\hline & \multicolumn{4}{|c|}{ at $80^{\circ} \mathrm{C}$} \\
\hline 30 & 2.1 & 5.6 & 0.6 & 20.7 \\
\hline 60 & 2.2 & 5.2 & 3.1 & 3.7 \\
\hline 90 & 1.7 & 6.8 & 2.0 & 5.7 \\
\hline 120 & 1.5 & 7.6 & 2.0 & 5.9 \\
\hline 180 & 1.8 & 6.3 & 1.4 & 8.2 \\
\hline \multirow[t]{2}{*}{240} & 1.4 & 7.9 & 1.4 & 8.2 \\
\hline & \multicolumn{4}{|c|}{ at $70^{\circ} \mathrm{C}$} \\
\hline 30 & 2.7 & 4.3 & 1.6 & 7.4 \\
\hline 60 & 1.5 & 7.5 & 1.1 & 10.6 \\
\hline 90 & 1.2 & 9.7 & 0.7 & 15.9 \\
\hline 120 & 1.0 & 11.6 & 0.5 & 21.5 \\
\hline 180 & 1.2 & 9.4 & 0.7 & 16.3 \\
\hline 240 & 0.8 & 14.1 & 0.9 & 13.2 \\
\hline
\end{tabular}

$k=$ first-order reaction rate constant, $t_{1 / 2}=$ half-life of anthocyanins

Table 3. Browning of sour cherry juices during heat treatment

\begin{tabular}{|c|c|c|c|c|c|c|}
\hline \multirow{3}{*}{$t / \min$} & \multicolumn{3}{|c|}{ Érdi bőtermő } & \multicolumn{3}{|c|}{ Kántorjánosi 3} \\
\hline & \multicolumn{6}{|c|}{ Temperature $/{ }^{\circ} \mathrm{C}$} \\
\hline & 90 & 80 & 70 & 90 & 80 & 70 \\
\hline 0 & $(0.25 \pm 0.02)^{\mathrm{Aa}}$ & $(0.25 \pm 0.02)^{\mathrm{Aab}}$ & $(0.25 \pm 0.02)^{\mathrm{Aab}}$ & $(0.21 \pm 0.01)^{\mathrm{Aa}}$ & $(0.21 \pm 0.01)^{\mathrm{Aa}}$ & $(0.21 \pm 0.01)^{\mathrm{Aa}}$ \\
\hline 30 & $(0.26 \pm 0.02)^{\mathrm{Aa}}$ & $(0.24 \pm 0.01)^{\mathrm{Aab}}$ & $(0.23 \pm 0.00)^{\mathrm{Aab}}$ & $(0.25 \pm 0.01)^{\mathrm{Aab}}$ & $(0.23 \pm 0.02)^{\mathrm{Aa}}$ & $(0.22 \pm 0.02)^{\mathrm{Aa}}$ \\
\hline 60 & $(0.27 \pm 0.02)^{\mathrm{Aa}}$ & $(0.24 \pm 0.01)^{\mathrm{Aa}}$ & $(0.23 \pm 0.01)^{\mathrm{Aab}}$ & $(0.25 \pm 0.01)^{\mathrm{Aab}}$ & $(0.25 \pm 0.04)^{\mathrm{Aba}}$ & $(0.22 \pm 0.01)^{\mathrm{Ba}}$ \\
\hline 90 & $(0.28 \pm 0.02)^{\mathrm{Aab}}$ & $(0.23 \pm 0.01)^{\mathrm{ABa}}$ & $(0.24 \pm 0.01)^{\mathrm{Ba}}$ & $(0.25 \pm 0.00)^{\mathrm{Aa}}$ & $(0.23 \pm 0.01)^{\mathrm{Ba}}$ & $(0.23 \pm 0.02)^{\mathrm{Ca}}$ \\
\hline 120 & $(0.29 \pm 0.03)^{\mathrm{Abab}}$ & $(0.25 \pm 0.01)^{\mathrm{Aab}}$ & $(0.26 \pm 0.01)^{\mathrm{Bab}}$ & $(0.26 \pm 0.01)^{\mathrm{Aab}}$ & $(0.22 \pm 0.01)^{\mathrm{Ba}}$ & $(0.23 \pm 0.01)^{\mathrm{Ca}}$ \\
\hline 180 & $(0.29 \pm 0.02)^{\mathrm{Aab}}$ & $(0.27 \pm 0.01)^{\mathrm{Ab}}$ & $(0.25 \pm 0.01)^{\mathrm{Bb}}$ & $(0.29 \pm 0.02)^{\mathrm{Aab}}$ & $(0.26 \pm 0.01)^{\mathrm{Ba}}$ & $(0.23 \pm 0.01)^{\mathrm{Ba}}$ \\
\hline 240 & $(0.38 \pm 0.01)^{\mathrm{Ab}}$ & $(0.30 \pm 0.03)^{\mathrm{Abab}}$ & $(0.25 \pm 0.01)^{\mathrm{Bab}}$ & $(0.31 \pm 0.02)^{\mathrm{Ab}}$ & $(0.26 \pm 0.02)^{\mathrm{Ba}}$ & $(0.24 \pm 0.04)^{\mathrm{Aba}}$ \\
\hline
\end{tabular}

The values are expressed as mean \pm standard deviation (S.D.), based on $N=3$ replicates. Different upper case letters indicate significant differences among treatments at different temperatures during the same time of treatment (read from left to right), whereas different lower case letters indicate significant differences among different treatment times at a given temperature (read from up downwards) 
where it remained the same. However, these results suggest minimal change in the quality of the sour cherry juices.

Both between-subject effects (treatment temperature and sour cherry cultivar) as well as the elapsed time (i.e. within-subject effect) had significant effects on the browning values $\left(\mathrm{F}_{\text {temperature }}(2 ; 12)=145.54\right.$ with $\mathrm{p}<0.001 ; \mathrm{F}_{\text {cultivar }}(1 ; 12)=$ 104.16 with $\mathrm{p}<0.001$ and $\mathrm{F}_{\text {time }}(3.95 ; 47.42)=24.515$ with $\mathrm{p}<$ 0.001 , respectively). Partial $\eta^{2}$ values were higher for between-subject effects $(0.96 ; 0.90)$ and lower for elapsed time effect (0.67), while the statistical power of the test was higher than 0.99 in each case. Interaction between temperature and the elapsed time was significant $\left(\mathrm{F}_{\text {tempera- }}\right.$ turextime $(7.9 ; 47.42)=5.37$ with $\mathrm{p}<0.001$ and $\eta^{2}=0.47$; statistical power is higher than 0.99); however, it was insignificant between elapsed time or temperature and cultivar $\left(\mathrm{F}_{\text {timex }}\right.$ cultivar $(3.95 ; 47.42)=2.32$ with $\mathrm{p}=0.07 ; \mathrm{F}_{\text {temperaturexcultivar }}(2 ; 12)=$ 2.16 with $\mathrm{p}=0.16)$, and for three-level type interaction $\left(\mathrm{F}_{\text {timex }}\right.$ temperaturexcultivar $(7.90 ; 47.42=1.14$ with $\mathrm{p}=0.36)$.

\section{Conclusions}

Sour cherry fruit is predominantly used for processing, therefore different properties of raw fruit are influenced by several technological processing steps during production. Results of this study revealed that the stability of anthocyanins in sour cherry juice depends on the level of heating. Between the two investigated juices of Hungarian sour cherry cultivars, Érdi bőtermő had higher amounts of total and cyanidin-based anthocyanins than Kántorjánosi 3 juice during the whole experiment; however, the concentration of anthocyanins in both juices was significantly affected by the thermal treatments. Comparing the two major anthocyanin components, cyanidin-3-rutinoside is more resistant to the heat treatment than cyanidin-3-glucosyl-rutinoside. Investigating the stability of anthocyanins, we found that they degraded more quickly with the increasing temperature; however, degradation of pigments depends on the cultivar. Anthocyanin concentrations decreased, while the browning of the juices considerably increased after $4 \mathrm{~h}$ of treatment at $90{ }^{\circ} \mathrm{C}$. Analysis of the combined data can be utilized for the selection of cultivars suitable for processing to health-beneficial sour cherry products. In conclusion, short-time heating at lower temperatures is recommended in order to maintain higher anthocyanin concentrations and achieve better quality parameters for sour cherry fruit juices.

\section{Acknowledgements}

The research was supported by the TÁMOP 4.2.1./B09/1/KMR-2010-0005 grant. We are also grateful to WATERS KFT (Budapest, Hungary) for the technical and scientific support.

\section{References}

1. FAOSTAT, Food and Agriculture Organization of the United Nations, Rome, Italy. http://faostat3.fao.org/download/Q/QC/E

2. Bonerz D, Würth $K$, Dietrich H, Will F. Analytical characterization and the impact of ageing on anthocyanin composi- tion and degradation in juices from five sour cherry cultivars. Eur Food Res Technol. 2007;224:355-64. http://dx.doi.org/10.1007/s00217-006-0328-7

3. Dóka O, Ficzek G, Bicanic D, Spruijt R, Luterotti S, Tóth M, et al. Direct photothermal techniques for rapid quantification of total anthocyanin content in sour cherry cultivars. Talanta. 2011;84:341-6.

http://dx.doi.org/10.1016/j.talanta.2011.01.007

4. Damar I, Eksi A. Antioxidant capacity and anthocyanin profile of sour cherry (Prunus cerasus L.) juice. Food Chem. 2012;135:2910-4. http://dx.doi.org/10.1016/j.foodchem.2012.07.032

5. Repajić M, Bursać Kovačević D, Putnik P, Dragović Uzelac V, Kušt J, Čošić Z, Levaj B. Influence of cultivar and industrial processing on polyphenols in concentrated sour cherry (Prunus cerasus L.) juice. Food Technol Biotechnol. 2015;53: 215-22.

http://dx.doi.org/10.17113/ftb.53.02.15.4151

6. Blando F, Gerardi C, Nicoletti I. Sour cherry (Prunus cerasus L.) anthocyanins as ingredients for functional foods. J Biomed Biotechnol. 2004;5:253-8. http://dx.doi.org/10.1155/S1110724304404136

7. Kirakosyan A, Seymour ME, Llanes DEU, Kaufman PB, Bolling SF. Chemical profile and antioxidant capacities of tart cherry products. Food Chem. 2009;115:20-5. http://dx.doi.org/10.1016/j.foodchem.2008.11.042

8. Dekazos ED. Anthocyanin pigments in red tart cherries. J Food Sci. 1970;35:237-41.

http://dx.doi.org/10.1111/j.1365-2621.1970.tb12146.x

9. Patras A, Brunton PN, O'Donell C, Tiwari BK. Effect of thermal processing on anthocyanin stability in foods; mechanisms and kinetics of degradation. Trends Food Sci Technol. 2010;21:3-10. http://dx.doi.org/10.1016/j.tifs.2009.07.004

10. Bakowska A, Kucharska AZ, Oszmianski J. The effects of heating, UV irridation, and storage on stability of the anthocyanin-polyphenol copigment complex. Food Chem. 2003; 81:349-55. http://dx.doi.org/10.1016/S0308-8146(02)00429-6

11. Castaneda-Ovando A, Pacheco-Hernandez ML, Paez-Hernandez ME, Rodriguez JA, Galan-Vidal CA. Chemical stability of anthocyanins: a review. Food Chem. 2009;113:859-71. http://dx.doi.org/10.1016/j.foodchem.2008.09.001

12. Lund DB. Heat processing. In: Karel M, Fennema OR, Lund DB, editors. Principles of food science, part II. Physical principles of food preservation. New York, USA: Marcel Dekker Inc.; 1975.

13. Cemeroglu B, Velioglu S, Isik S. Degradation kinetics of anthocyanins in sour cherry juice and concentrate. J Food Sci. 1994;69:1216-8.

http://dx.doi.org/10.1111/j.1365-2621.1994.tb14680.x

14. Sadilova E, Stintzing FC, Carle R. Thermal degradation of acylated and nonacylated anthocyanins. J Food Sci. 2006;71: 504-12. http://dx.doi.org/10.1111/j.1750-3841.2006.00148.x

15. Brownmiller C, Howard L, Prior RL. Processing and storage effects on monomeric anthocyanins, percent polymeric colour, and antioxidant capacity of processed blueberry products. J Food Sci. 2008;73:72-9.

http://dx.doi.org/10.1111/j.1750-3841.2008.00761.x.

16. Patras A, Brunton NP, Da Pieve S, Butler F. Impact of high pressure processing on total antioxidant activity, phenolic, ascorbic acid, anthocyanin content and colour of strawberry and blackberry purées. Innov Food Sci Emerg Technol. 2009; 10:308-13.

http://dx.doi.org/10.1016/j.ifset.2008.12.004 
17. Rhim JW. Kinetics of thermal degradation of anthocyanin pigment solution driven from red flower cabbage. Food Sci Biotechnol. 2002;11:361-4.

18. Kirca A, Özkan M, Cemeroglu B. Stability of black carrot anthocyanins in various fruit and nectars. Food Chem. 2006;97: 598-605.

http://dx.doi.org/10.1016/j.foodchem.2005.05.036

19. Füleki T, Francis FJ. Quantitative methods for anthocyanins. Purification of cranberry anthocyanins. J Food Sci. 1968;33: 266-74. http://dx.doi.org/10.1111/j.1365-2621.1968.tb01365.x

20. Adams JB. Thermal degradation of anthocyanins with particular reference to the 3-glycosides of cyanidin. I. In acidified aqueous solution at $100{ }^{\circ} \mathrm{C}$. J Food Sci Agr. 1973;24: 747-62. http://dx.doi.org/10.1002/jsfa.2740240702

21. Simard RE, Bourzeix M, Heredia N. Factors influencing colour degradation in black currant juice (Ribes nigrum L.). Sci Aliment. 1981;1:388.

22. Verbyest L, Van Crombruggen K, Van der Plancken I, Hendrickx M, Van Loey A. Anthocyanin degradation kinetics during thermal and high pressure treatments of raspberries. J Food Eng. 2011;105:513-21. http://dx.doi.org/10.1016/j.jfoodeng.2011.03.015

23. Garzon GA, Wrolstad RE. Comparison of the stability of pelargonidin-based anthocyanins in strawberry juice and concentrate. J Food Sci. 2002;67:1288-99.

http://dx.doi.org/10.1111/j.1365-2621.2002.tb10277.x
24. Wang WD, Xu SY. Degradation kinetics of anthocyanins in blackberry juice and concentrate. J Food Eng. 2007;82:271-5. http://dx.doi.org/10.1016/j.jfoodeng.2007.01.018

25. Kirca A, Özkan M, Cemeroglu B. Effects of temperature, solid content and $\mathrm{pH}$ on the stability of black carrot anthocyanins. Food Chem. 2007;101:212-8. http://dx.doi.org/10.1016/j.foodchem.2006.01.019

26. Obón JM, Díaz-García MC, Castellar MR. Red fruit juice quality and authenticity by HPLC. J Food Compos Anal. 2011;24:760-71. http://dx.doi.org/10.1016/j.jfca.2011.03.012

27. Stintzing FC, Trichterborn J, Carle R. Characterisation of anthocyanin-betalain mixtures for food colouring by chromatic and HPLC-DAD-MS analyses. Food Chem. 2006;94:296-309. http://dx.doi.org/10.1016/j.foodchem.2005.01.018

28. Jakobek L, Seruga M, Medvidovic- Kosanovic M, Novak I. Anthocyanin content and antioxidant activity of various red fruit juices. Deutsch Lebensm Rundsch. 2007;103:58-64.

29. Kirca A, Cemeroglu B. Degradation kinetics of anthocyanins in blood orange juice and concentrate. Food Chem. 2003;81: 583-7. http://dx.doi.org/10.1021/jf900836b

30. Boyles MJ, Wrolstad RE. Anthocyanin composition of red raspberry juice: influences of cultivar, processing and environmental factors. J Food Sci. 1993;58:1135-41. http://dx.doi.org/10.1111/j.1365-2621.1993.tb06132.x 